\title{
[1]
}

Journal of Ethnic and Migration Studies

Vol. 36, No. 10, December 2010, pp. 1565-1586

올 Routledge

Taylor \& Francis Grou

\section{Understanding Global Migration: A Social Transformation Perspective}

\section{Stephen Castles}

This article aims to examine some of the difficulties of theory formation in international migration studies, and to suggest a response. The starting point is an examination of the dominant perception of 'migration as a problem'. This is followed by a discussion of some key obstacles to theoretical advancement in migration studies. I argue that a general theory of migration is neither possible nor desirable, but that we can make significant progress by re-embedding migration research in a more general understanding of contemporary society, and linking it to broader theories of social change across a range of social scientific disciplines. A conceptual framework for migration studies should take social transformation as its central category, in order to facilitate understanding of the complexity, interconnectedness, variability, contexuality and multi-level mediations of migratory processes in the context of rapid global change. This would mean examining the links between social transformation and human mobility across a range of sociospatial levels, while always seeking to understand how human agency can condition responses to structural factors. The argument is illustrated through the example of the changing dynamics of labour forces in highly developed countries.

Keywords: Migration Theory; Social Theory; Social Transformation; Socio-Spatial Levels; Agency; Structure

More than ten years ago, Massey et al. (1998: 3) argued that:

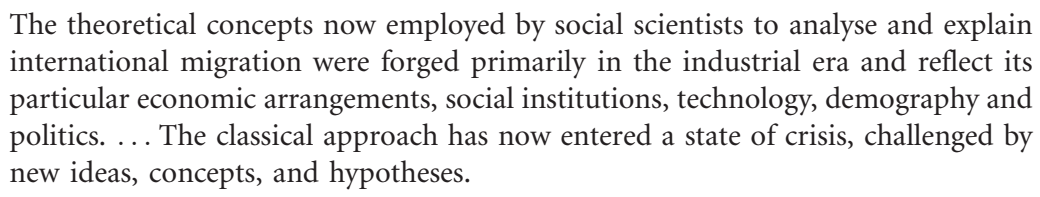

Stephen Castles is Research Professor of Sociology at the University of Sydney. Correspondence to: Prof. S. Castles, School of Social and Political Sciences, University of Sydney, NSW 2006, Australia. E-mail: stephen.castles@sydney.edu.au. 
Although, as they pointed out, 'these new ways of thinking have not yet cohered into a single theory', Massey and his colleagues believed that 'the time has come ... to reassess theories of international migration and bring them into conformity with new empirical conditions'. The 'post-industrial, post-Cold War world' needed a new theory of migration appropriate for 'a brand new century' (1998: 3). This was the programmatic statement of a very important book, which did indeed set out to present a new synthesis as a basis for a 'single' (and implicitly general) theory.

Twelve years later, the exponential growth of social-scientific research into the international mobility of people continues: we have more researchers, university courses, students, research projects, institutes, conferences, journals and publications than ever before. Yet the quest for a generally accepted theoretical framework for migration studies remains elusive. We still lack a body of cumulative knowledge to explain why some people become mobile while most do not, and what this means for the societies concerned. Although there does seem to be agreement on some matters - the importance of migration networks for example - we do not have a common conceptual framework that could serve as the starting point for intellectual debates and the formulation of hypotheses and research questions.

This article starts by examining the 'sedentary bias' in migration debates, and goes on to discuss why it is so difficult to develop and agree on a conceptual framework for migration studies. A key problem is the tendency to see migration as quite distinct from broader social relationships and change processes. I will argue for the need to embed migration research in a more general understanding of contemporary society. This requires forms of inquiry that start from a situation of rapid and generalised changes. I refer to these processes as social transformation, as a convenient label to facilitate discussion of the complexity, interconnectedness, variability, contextuality and multi-level mediations of global change. The article links the analysis of migration to important trends in the theory and methodology of various social scientific disciplines, and illustrates interdisciplinary social transformation research by looking at the example of labour force change in northern economies.

My analysis points to rather different conclusions than Alejandro Portes' (2010) article (in this special issue of JEMS). Portes argues that migration does not generally change the fundamental structures and institutions of developed societies. By contrast, I will argue that migration is actually one part of the process of transformation of these structures and institutions, which arises through major changes in global political, economic and social relationships.

\section{Migration, Mobility and the 'Sedentary Bias'}

Some analysts have suggested that we should abandon the term migration, because it is thought to imply long-term movement from one nation-state to another, following the patterns of labour and settlement migration seen as typical of the nineteenth and twentieth centuries. The twenty-first century, by contrast, is regarded as an era of fluidity and openness, in which changes in transportation, technology and culture are 
making it normal for people to think beyond borders and to cross them frequently (Urry 2007). Movements for purposes of study, professional advancement, marriage, retirement or lifestyle are assuming greater significance, so that older ideas on migration are thought to be no longer relevant.

But this picture seems overdrawn: indeed, as Bauman (1998) had pointed out, the right to be mobile is more class-specific and selective than ever. National border controls and international cooperation on migration management have become highly restrictive. Most people have neither the economic resources nor the political rights needed for free movement. Only 3 per cent of the world's population are international migrants (UNDESA 2005). The postmodern utopia of a borderless world of mobility has not yet dawned, so that it still seems appropriate to focus on migration as a process based on inequality and discrimination, and controlled and limited by states.

The migration-mobility debate can be located in a political discourse. In the years leading up to the financial crash of 2008, demographic, economic and social factors combined to make highly developed economies increasingly reliant on immigrant labour (Castles 2006; CEC 2005a). International recruitment of highly skilled personnel was considered valuable, while lower-skilled migrant workers were seen as out-of-place in shiny new post-industrial economies. Movements of the highly skilled were celebrated as professional mobility, while those of the lower-skilled were condemned as unwanted migration. Mobility equalled good, because it was the badge of a modern open society; migration equalled bad because it re-awakened archaic memories of invasion and displacement. But it seems to me that a focus on migration, rather than mobility, better reflects real power relations. There is good reason to believe that the structural factors driving labour migration-particularly from low- and middle-income countries to richer countries - will quickly reassert themselves after the global financial crisis (GFC) of 2007-09.

A further point is relevant here: a dominant political discourse sees migration as a problem that needs to be 'fixed' by appropriate policies. The repressive variant is tight border control, the more liberal one is addressing the 'root causes' of migrationespecially poverty and violence in origin countries - so that people do not have to migrate. Either way, migration is seen as harmful and dysfunctional. Bakewell (2007) has shown how this discourse - which he calls the sedentary bias - continues a long tradition which started with colonial policies and is continued by most contemporary development agencies: the poor constitute a threat to prosperity and public order if they move, and should therefore stay at home. However, since rich countries need migrant workers, the current expression of the sedentary bias is not a prohibition of South-North movements of the lower-skilled, but rather the idea that circular migration is a 'win-win-win situation' for labour-importing countries, origin countries and the migrants themselves (CEC 2005b).

Yet historical perspectives show that migration has been a normal aspect of social life - and especially of social change-throughout history. The reason for the expansion of migration - especially over long distances - since the sixteenth century 
was the accelerated pace of change connected with the development of the capitalist world market. Nation-state formation, colonial expansion and imperialism involved conflict, violence, development-induced displacement and the growth of forced migration. Migration in the colonial period took both the form of movement of administrators, traders and military personnel (in modern terms, professional mobility), and migration based on inequality and coercion: slaves, indentured workers etc. (Cohen 1995).

But migration also often has positive consequences for migrants and their communities of origin. People may move from areas where there are low incomes and few opportunities to places where economic growth and innovation present them with new opportunities. Return flows of remittances, technology and ideas may, under certain circumstances, lead to positive changes in areas of origin. The UN Development Programme's 2009 Human Development Report draws attention to the potential of migration to enhance human capabilities and well-being (UNDP 2009).

The great wave of industrialisation from the nineteenth to the early twentieth century led to what Hatton and Williamson call the first 'age of mass migration' (Hatton and Williamson 1998, 2005), while the accelerated globalisation of the post1945 period led to a second 'age of migration'. This current wave has gone much further than the first, because it has drawn in virtually all regions of the world, while the first focused mainly on the 'Atlantic economy' (Castles and Miller 2009). Migration has grown more than ever in the last 30 years because of the accelerated pace of globalisation. The 'only 3 per cent of global population' figure (see above) obscures the significance of migration as an expression of social change and a ferment for further change, because it glosses over the highly concentrated nature of migration: cultures of emigration have become established in certain origin areas, while settlement of immigrants is concentrated in developed countries (accounting for 10-25 per cent of the population of OECD states) and cities (20-45 per cent in many global cities). Moreover, far more people move within their own countries than internationally (King and Skeldon 2010, this issue)-although they, too, may encounter legal, economic, cultural and social obstacles. The problem is not migration itself, but rather the conditions of inequality under which most SouthNorth migration takes place. These lead to marginalisation and exploitation for many migrants. Development will not reduce migration (de Haas 2006). If there were less inequality (and therefore less poverty and human insecurity) there would not be less migration, but it would take place under very different circumstances.

These considerations reflect the difficulty of separating between the social-scientific and the political in understanding migration. Claims of academic neutrality can mask a sedentary bias - an unquestioning assumption that migration is a bad thing. Yet theories of global migration should not be based on the normative objective of finding ways of helping people to stay at home. Rather they should be based on the postulate that migration is a normal part of social relations. They should help us analyse the dynamics of migration, not in isolation, but as a part of complex and varied processes of societal change. If there is a normative goal, it should not be to 
Journal of Ethnic and Migration Studies 1569

reduce migration but to find ways in which it could take place under conditions of equality and respect for human rights.

\section{The Rocky Road Towards a 'Single Theory' of Migration}

This section discusses some of the formidable obstacles to theoretical advancement in migration studies. These topics have been dealt with extensively in the literature, so they will only be addressed briefly here.

\section{Interdisciplinarity}

Natural sciences build on an accepted and cumulative body of knowledge, arising from past theoretical and empirical work, and serving as a basis for formulating hypotheses, questions and methodology for new research. This does not imply static and dogmatic theory, since 'scientific revolutions' (Kuhn 1996) may lead to a revision of fundamental ideas. Some social sciences (such as economics and demography) try to emulate the natural sciences by putting forward models based on quantitative data, but others (such as anthropology and sociology) cannot, due to the unpredictability and complexity of the groups and relationships they deal with, and the frequent lack of quantifiable data. Indeed, it could be argued that the models used in economics and demographics actually reflect over-simplification of complex and diverse patterns of behaviour (Castles 2008), and therefore need to be linked to the insights of other disciplines, but the point here is that other social sciences cannot even try to avoid the complexity and messiness of the real world.

It is hard for an interdisciplinary field like migration studies to develop an agreed body of knowledge, and this problem has been compounded by the rapid growth of the field over the last 20-30 years. As new researchers have been drawn into the study of migration, they have, not surprisingly, applied the conceptual and methodological tools of their disciplines. The incentive structures of the discipline-based academic hierarchy make this hard to avoid. The result is that migration research is compartmentalised, with little analytical and methodological collaboration across boundaries. The disciplinary bias has often meant reductionist approaches that focus on limited aspects of migratory experiences, blocking understanding of the whole migratory process.

Migration embraces all dimensions of social existence, and therefore demands an interdisciplinary approach. Efforts have been made to achieve this through interdisciplinary research teams, as well as through theoretical work designed to 'talk across disciplines' (Brettell and Hollifield 2007). However, attempts at interdisciplinarity have all-too-often been more additive than integrative-with each discipline contributing aspects susceptible to its mode of analysis, but without an overarching synthesis. Indeed the problem of fragmentation is not just between but also within disciplines. For instance the schisms between neo-classical economic theory and the 'new economics of labour migration', or between functionalist and 
1570 S. Castles

historical-institutional approaches in sociology, seem as profound as those between, say economic or legal approaches to migration.

\section{Fragmentation on the Basis of Spatial or Functional Criteria}

Massey and his collaborators point out that migration studies is split into research on the causes, processes and patterns of migration itself (they speak of 'determinants of migration'), and research on how migrants become incorporated into receiving societies ('immigrant assimilation'). In fact there are several other divisions.

Researchers on internal migration often have little interchange with those working on international migration. Studies of migration in less-developed countries often take poverty research as a starting point, and may be poorly linked to other areas of migration research. Studies of migration in specific regions are often linked to area studies (African Studies, Middle Eastern Studies and so on), and may be formulated in spatially specific terms, with little dialogue with social scientists working elsewhere. Forced migration research is often quite separate from other areas of migration studies, and has two distinct prongs: asylum and refugees in the North, and humanitarian issues in the South. The emerging sub-field of migration and development has tried to cross disciplinary boundaries, but has been too bound up with politics and policies in its relatively short history to contribute strongly to theory formation.

Migration scholars tend to be highly specialised, and each sub-field has distinct literatures and bodies of knowledge. There are separate research centres, journals and conferences. Results include a failure to understand the historical character of migration, false assumptions of one-way causality, and an inability to understand the overall dynamics of migratory processes and their embeddedness in processes of societal change.

\section{Closeness to Political and Bureaucratic Agendas}

The social sciences originated in industrial societies where all types of social relationships were seen as politically and culturally framed by the nation-state (Connell 1997; Faist 2000). Beck argues that contemporary social theory is still trapped in the 'dead end of 'methodological nationalism' (Beck 2007), a problem which is particularly severe for migration studies (Wimmer and Glick Schiller 2003) because control of belonging to the national community has always been central to nation-state sovereignty. Today migration research still tends to be linked to specific historical experiences of managing migration and diversity (Vasta and Vuddamalay 2006).

The recent politicisation of issues of migration and incorporation of migrants has sharpened the dilemma of policy-driven research. Governments have commissioned a large volume of research on these topics. This has provided funding for empirical work, opened up new research areas and encouraged the expansion of migration 
studies. However, government-commissioned work can also mean that research questions, methods and even findings may be shaped by policy interests. Policydriven research often provides simplistic, short-term remedies to complex, long-term social issues. Much policy-driven research is not only bad social science-it is also a poor guide to successful policy formation, and one reason for the poor record of many governments in the area (Bhagwati 2003; Castles 2004).

\section{The Receiving Country Bias}

Most migration research has taken the situation in northern destination countries as its starting point, neglecting the perspectives of origin and transit countries, and of migrants. This is not surprising, since research funding and capacities are concentrated in the North. When the US Social Science Research Council (SSRC) held its first major conference on migration theory in 1996, it commissioned papers exclusively from US scholars. The resulting publications (Hirschman et al. 1999; Portes 1997) focused mainly on issues of incorporation of immigrants into society (assimilation, pluralism etc.) and on the impact on 'American life and institutions'. A few years later, the SSRC and Princeton University sought to extend the debate by including 'immigration scholars from both sides of the Atlantic' (Portes and DeWind 2004a: 828). European efforts to review the 'state-of-the-art' in migration theory have also been mainly northern-centric (Penninx et al. 2006).

Recent debates on migration and development have led to a broadening of approach and a realisation of the need for the cooperation of scholars from destination, transit and receiving countries. International agencies (such as IOM, ILO and UNESCO) have tried to build networks that include southern researchers. Publications like the Manila-based Asian and Pacific Migration Journal increase the dissemination of southern research. The US SSRC's initiative on migration and development in 2008 included several southern scholars. ${ }^{1}$ The Global Commission on Migration and Development (GCIM 2005) and the Global Forum on Migration and Development (GFMD) have included southern policy-makers, civil society and academics. The 'perspective from the south' (Castles and Delgado Wise 2008; Manuh 2005) is beginning to be included in international debates.

Yet there is little sign that such trends have had much effect on the dominant approaches in migration studies. In Europe, the main policy emphasis is still on the costs and benefits for receiving societies, and on questions of migration control (or, more euphemistically, 'migration management'). One reflection of this is the renewed preoccupation with assimilation. In the 1970s and 1980s, many countries had shifted away from assimilationist approaches to migrants and minorities. But the trend towards multiculturalism or pluralism came to a halt in the 1990s, in the face of political and media claims of supposed threats to national identity and security from migrants (especially Muslims). New policy trends are reflected in a revamping of social scientific theories of assimilation. Neo-assimilationist approaches (Alba and Nee 1997; Entzinger 2003; Joppke and Morawska 2003) have recently been joined by 


\section{S. Castles}

discourses on social cohesion and social capital, which claim that diversity endangers the solidarity on which democratic nation-states are founded (see Vasta 2007). Such social-scientific accounts have in turn helped to justify changes in national policies, such as the introduction of 'integration contracts' and citizenship tests in such states as France, Germany, Britain, the Netherlands and Australia.

\section{Isolation of Migration Studies from Broader Trends in Contemporary Social Theory}

Migration scholars have often found themselves marginalised within the social sciences because many leading social theorists do not consider migration as an important area of investigation. The fact that migration studies cuts across disciplinary boundaries is one reason why it has gained little acceptance in mainstream departments. As a result migration research often takes place in dedicated research centres heavily dependent on external funding. This forces migration researchers to take on policy-driven consultancy work-which in turn confirms the prejudice against interdisciplinary study on the part of mainstream social scientists.

To understand this fully would require a detailed study of the institutional and intellectual characteristics of the social sciences in each country. In Britain for instance, the initial response to the New Commonwealth immigration of the 1950s and 1960s was the reworking of the pre-World War II Chicago School of Sociology's theories of assimilation and acculturation. However, by the 1970s, issues of racism, cultural identity, class and gender-influenced considerably by black, feminist and Marxist scholars - began to play an important role. In the meantime such approaches have become part of the accepted body of social analysis, but have not always moved on to embrace the newer complex forms of global mobility affecting the UK. In recent years, the problem of disciplinary barriers has worsened, because Britain's Research Assessment Exercise has put such a premium on publication in disciplinary journals that young academics fear the consequences of publishing in migration journals.

Globalisation theory is now at the centre of international social science debates, and the mobility of people is a crucial form of globalisation. Yet many of the seminal works on globalisation, like those of Castells (1996, 1997, 1998), Albrow (1996) and Beck (1997), pay scant attention to the mobility of people. There are contrasting examples, as will be discussed below, yet analysis of migration as a central element of global social change is still the exception.

\section{Complexity, Diversity and Context}

A major obstacle to theory formation is the complexity and diversity of migration experiences. This has posed particular problems for economists. The Harris-Todaro model that underpins the neo-classical approach assumes that movement is motivated by the desire for individual income maximisation, based on rational comparison of the relative costs and benefits of remaining at home or moving. The 
mere existence of economic disparities between various areas should be sufficient to generate migrant flows. In the long run, such flows should help to equalise wages and conditions in underdeveloped and developed regions, leading towards economic equilibrium. This model was developed to analyse internal movements in developing countries, but is seen as applicable to international migration too, provided that consideration is given to constraints arising from the role of states and their uneven power. This model suggests a long-term transition to 'a one-sector, relatively fullemployment neo-classical world' (Ranis 2009: 5).

But the neo-classical model has not proved very useful for analysing and explaining actual migration experiences. Its narrow focus on income maximisation and its assumption of rational economic decision-making based on full information have little to do with the reality of most migration flows. This led some economists to criticise neo-classical methodological individualism. The protagonists of the 'new economics of labour migration' (Stark 1991; Taylor 1999) focus on family strategies for income maximisation and risk diversification. NELM researchers use ethnographic research methods (such as qualitative interviews and household studies) to understand migration decisions, but retain an emphasis on rational economic decision-making. NELM theories still largely fail to take account of the many noneconomic factors that shape migration.

Collinson (2009) suggests the need for a political economy approach to migration that links the analysis of local-level factors that influence people's migration decisions and livelihood strategies, with political, economic and social factors at various levels that affect the agency of the migrant. That would mean, as Collinson (following Gold 2005) suggests, examining:

[t]he inter-linkages between different migration streams; the importance of agency, autonomy, perceptions, cultural and historical factors and institutional constraints; the complex multi-level and transnational nature of migration; and the importance of social groups and relationship - including migration networks - for shaping migration dynamics and migration experiences, straddling migration 'sending', 'receiving' and 'transit' locations, and a range of actors within them (Collinson 2009: 5-6).

This list indicates the great complexity of migratory processes. Economic factors are important, but hardly ever sufficient to understand any specific experience. Complexity also implies diversity: if there are so many factors at work, the possible combinations become infinite. This in turn points to the crucial role of context - the links between migration and the other economic, social, political and cultural relationships at work in particular places at a particular historical juncture. An historical understanding of societies and the relationships between them is crucial. For instance, no analysis of migration to Britain could be complete without an understanding of the history of British colonialism and racism; no analysis of Mexican migration to the USA could be valid without consideration of the historical expansion of the USA and its past labour recruitment policies. 


\section{S. Castles}

From Grand Theory to Interdisciplinary Middle-Range Theory

Migration theory needs to provide a framework for understanding the dynamics of international migration and incorporation in a situation of rapid and complex transformation (cf. King 2002). But can general theory do this? General theories are rarely cross-disciplinary-rather they tend to postulate logical structures that cover all conceivable forms of behaviour from the theoretical perspective of a single discipline. That is why the label of 'grand theory' is often applied in sociology to Talcott Parsons' 'social system' (Parsons 1951) or Niklas Luhmann's idea of a 'world society' (Luhmann 1990). The complexity of migratory behaviour, that goes across all areas of human existence, cannot be readily accommodated within such elegant structures. As I discussed in an earlier JEMS article (Castles 2007), Alejandro Portes has argued strongly against the idea of an all-embracing general theory for migration studies. Rather, researchers should focus on the complexity, contradictions and unintended consequences of social action (Portes 1997; Portes and DeWind 2004b). This implies returning to Merton's concept of 'theories of the middle-range': 'special theories applicable to limited ranges of data-theories for example of class dynamics, of conflicting group pressures, of the flow of power and the exercise of interpersonal influence ...' (Merton 1957: 9).

In migration research, a middle-range theory would allow analysis of the regularities and variations in specific types of migration that share some important common characteristics: for instance flows of different types (e.g. labour migration and asylum migration) belonging to a single migratory system (e.g. the system linking France and Algeria, or Britain and Nigeria). Another example could be labour migration flows from poor to rich countries in a specific economic phase (e.g. the period of neoliberal globalisation from the 1970s to 2008) across a range of migration systems (such as that linking South Asia and the Gulf, or that linking South-East and East Asia). Such middle-range theories could bring together the insights provided by all the different social sciences concerned with migration. What middle-range theories could not - and should not - aspire to do is to provide rules for analysing all types of migration regardless of time or location.

In Worlds in Motion (1998), Massey and his colleagues state that: 'Our review suggests the outlines of what an integrated theory of international migration should look like'. It should contain:

...four basic elements: a treatment of the structural forces that promote emigration from developing countries; a characterisation of the structural forces that attract immigrants into developed countries; a consideration of the motivations, goals and aspirations of the people who respond to these structural forces by becoming international migrants; and a treatment of the social and economic structures that arise to connect areas of out- and in-migration. Any theoretical explanation that embraces just one of these elements will necessarily be incomplete and misleading... (Massey et al. 1998: 281). 
These four elements cover the key aspects of an interdisciplinary conceptual framework for migration studies, for they embrace not only macro-structures in origin and destination areas, but also include the meso-structures developed to link these in migratory processes, and - importantly - the human agency of the migrants themselves. However, a serious problem remains: that of linking this overarching perspective with the specific, disciplinary theories reviewed so ably in Worlds in Motion. Massey et al. claim that:

... all theories play some role in accounting for international migration in the contemporary world, although different models predominate at different phases of the migration process, and different explanations carry different weights in different regions depending on the local circumstances of history, politics and geography (1998: 281).

Thus they argue that world systems theory is best for explaining emigration from developing countries, while bits of world systems theory, segmented labour market theory and neo-classical macro-economics can be cobbled together to explain the forces attracting migration to developed destination countries - and so on for the rest of the four 'basic elements' (Massey et al. 1998: 281). It is hard to see this eclectic approach as the basis for 'integrated theory' or even for a coherent analytical framework. Indeed there seems to be a risk of making fairly arbitrary choices about which bit of theory to use in which circumstances.

Such considerations help to clarify the requirements for migration theory: it should take the form of a broad conceptual framework, which can help to integrate the analyses of specific migratory processes by the various social science disciplines. However, this framework cannot use various theoretical approaches in an arbitrary way by choosing the bits that fit and leaving out those that do not. A conceptual framework needs to be capable of accommodating all the factors and interactions that shape a given migratory process. However, this does not mean producing a contradiction-free analysis. A lack of coherence in findings across disciplines, paradigms and methodologies may be an important indicator of knowledge and research gaps, but can also show the need to revise the conceptual framework. This is how middle-range theory develops - without ever aspiring to present a universally valid truth.

\section{A Social Transformation Framework for Migration Studies}

Awareness of complexity, diversity and the importance of context might lead to the idea that theory formation is pointless, since each case appears different. This could encourage a postmodern fragmentation of knowledge, based on the idea that everything is specific and that there are no broad social trends or institutional patterns. Yet such a perspective would ignore the reality of global integration processes that lead to higher and more pervasive levels of economic, political, social and cultural integration than ever before. Contemporary social relations do offer 


\section{S. Castles}

great diversity, but it is diversity within increasingly universal relationships of power and inequality. Thus the most important way to achieve advancement in migration studies is to link it more closely to wider social theory.

\section{Re-Embedding Migration in Social Transformation}

Analysis of processes of social transformation could provide the basis for a new understanding of the links between human mobility and global change. Social transformation can be defined as a fundamental shift in the way society is organised that goes beyond the continual processes of incremental social change that are always at work. This implies a 'step-change' in which all existing social patterns are questioned and many are reconfigured. Social transformations are closely linked to major shifts in dominant economic, political and strategic relationships.

A useful point of departure for a contemporary theory of social transformation is Polanyi's (2001) work (first published in 1944) on the 'great transformation' of European societies. According to Polanyi, the market liberalism of the nineteenth century ignored the embeddedness of the economy in society (i.e. its role in achieving social goals laid down by politics, religion and social custom). The liberal attempt to disembed the market was a 'stark utopia' leading to a double movement - a protective counter-movement to re-subordinate the economy to society. Unfortunately, in the early twentieth century, the counter-movement lead inexorably to fascism and world war (Polanyi 2001).

The closely linked processes of accelerated economic globalisation and the reshaping of political and military power relationships since the end of the Cold War represent a contemporary step change - a new 'great transformation'. These fundamental economic and political shifts are closely interwoven with a transformation of social relationships. At the structural level, social transformation in developed countries can be seen in the closure of older industries, the restructuring of labour forces, the erosion of welfare states, the fragmentation of communities and the reshaping of social identities. In less-developed countries, forms of social transformation include intensification of agriculture, destruction of rural livelihoods, erosion of local social orders, and formation of shanty-towns within new mega-cities.

Polanyi's idea of the 'double movement' can be seen through the modern lens of the concept of agency. Social transformation processes are mediated by local historical and cultural patterns, through which people develop varying forms of agency and resistance. These can take the form of religious or nationalist movements, but also of individual- or family-level livelihood strategies, including rural-urban or international migration. The recent upsurge in South-North migration can best be understood through examination of these changes and their complex linkages. Here too we can examine agency, for instance in the new social movements which have emerged: in 2006 alone, for instance, there were major strike movements of South Asian workers in the Gulf states, demonstrations of migrants in the USA for 
legalisation and rights, and movements of youth of migrant origin against police repression in France.

In the past, research on migration has had little impact on core theories of social order and differentiation. However, in recent times, globalisation has challenged national models in the social sciences and drawn attention to cross-border flows as key instruments of change. There are signs of a new emphasis on human mobility, and some major works on global change (such as Bauman 1998; Beck 2007; Cohen and Kennedy 2000; Held et al. 1999) now stress the centrality of migration in social relations. This shift is not surprising: if the principle of the 'container society' in which all social relationships take place within the nation-state (Faist 2000) is no longer sustainable (even as a myth), then flows across borders become a crucial area of investigation for the social sciences.

The concept of embeddedness can play an important part in understanding globalisation and its consequences for human mobility. Just as nineteenth-century liberals portrayed economic affairs as separate from the rest of society, neoliberals have promoted globalisation as a predominantly economic phenomenon. The 'new economy' was depicted as the result of growing foreign direct investment, the deregulation of cross-border flows of capital, technology and services, and the creation of a global production system (Petras and Veltmayer 2000: 2). According to the neoliberal ideology, the superior efficiency of this new economic world was guaranteed by the rationality of decision-making in multinational corporations (MNCs) and by the 'invisible hand' of global financial and commodity markets. The basic premise of globalisation was 'the leadership of civilization by economics' (Saul 2006: xi). This ideology was summed up in the 'Washington consensus' on the importance of market liberalisation, privatisation and deregulation (Stiglitz 2002: 67).

But the neoliberal attempt to disembed economic globalisation from its societal context was in fact deeply political, because it made global change appear as an inevitable and desirable form of modernisation - that could only be resisted by backward peoples or fundamentalist leaders. Clearly globalisation was not just about economics: it was also a political process, conceived in ideological terms:

For the theorists of this process and its many advocates these flows..., together with the resulting economic integration and social transformation, have created a new world order with its own institutions and configurations of power that have replaced the previous structures associated with the nation-state, and that have created new conditions of peoples' lives all over the world (Petras and Veltmayer 2000: 2).

The globalisation paradigm emerged in the context of the political strategies of the Reagan-Thatcher era designed to roll back the welfare states and the relatively high wage levels of the postwar boom period. Economic deregulation, the opening of markets and the weakening of trade unions led to major social changes in the USA and Britain. Other developed countries were compelled to review their welfare states 


\section{S. Castles}

and 'social wages' to remain competitive, leading to a decline in labour protection and an increase in labour-market segmentation, issues I return to discuss below.

Even a neoliberal world economy needs control mechanisms, but these were to be provided not by national governments (which, in some cases at least, were democratically elected), but by international institutions, especially the International Monetary Fund (IMF), the World Bank and the World Trade Organisation (WTO). Their task was not to protect weak economies or vulnerable social groups, but rather to ensure that all economies and societies were exposed to the cold winds of competition-particularly through the mechanism of 'structural adjustment programmes' (Stiglitz 2002). The neoliberal dream was undermined by the nearmeltdown of the global finance sector in 2007-09. Although economists and politicians now speak of a 'post-Washington consensus' approach to world trade and investment, fundamental changes in economic power and governance have yet to emerge.

A theory of global change in which the economy is seen as disembedded from society, and the political and social consequences are treated as inevitable 'externalities' (as economists put it), leads also to a disembedded understanding of migration. This means seeking the determinants of migration in a range of rational choices based on economic interests. The essential link to massive changes in global economic and political power relationships and the resulting social transformation processes is absent.

An alternative approach is to conceptualise migration not merely as a result of social transformation, nor as one of its causes, but as an integral and essential part of social transformation processes. That means that theories of migration should be embedded in broader social theory. It also means that research on any specific migration phenomenon must always include research on the societal context in which it takes place. Finally, because awareness of change starts usually at the local level, it is important to link local-level experiences of migration (whether in origin or receiving areas) with other socio-spatial levels - and particularly with global processes.

\section{Social Transformation Theory and Migration Theory}

We can draw on emerging ideas from a range of disciplines to develop a new approach to understanding transformation-migration relationships. In economics, Stiglitz has provided a critique of neoliberal economic globalisation, derived from Polanyi's concept of transformation (Stiglitz 1998, 2002). For him, the 'double movement' is represented by anti-globalisation activism (see Stiglitz's foreword to Polanyi 2001). Milanovic (2007) shows that the neoliberal claim of improving economic outcomes for poor countries has masked a vast increase in inequality. In political economy, the neoliberal model is criticised as a new utopia of a selfregulating world economy (Petras and Veltmayer 2000; Weiss 1998). Such ideas echo Polanyi's critique of attempts to disembed the economy from society, but they are essentially top-down critiques, which fail to analyse the local effects of global 
economic and political forces. In this respect, critical theories and neoliberal approaches show a certain similarity in their determinism and exclusion of agency.

This one-sidedness can be countered by applying concepts and methodologies suggested by sociologists, geographers and anthropologists. The International Sociological Association (ISA) Research Committee on 'Social Transformation and Sociology of Development' (Schuerkens 2004) uses the concept of 'glocalisation' to analyse links between global forces and local life-worlds, and has applied this approach to the study of migration and ethnicity. Other sociologists show how identity movements arise in reaction to globalisation (Castells 1997). Social geographers have developed new ways of understanding the changing meaning of 'territory' and the relationships between spatial levels (Lussault 2007; Sassen 2006). Social anthropology has moved away from older ideals of authenticity and singularity to study individual and group reactions to globalising forces (Levitt and Glick Schiller 2004).

Such trends in social theory have had considerable influence on migration studies. As already mentioned, economists have become increasingly critical of the assumptions of neo-classical theory, and are investigating the role of families, communities, and other social actors in migratory processes. The 'new economics of labour migration' seeks to overcome neo-classical methodological individualism by using household surveys to understand how migration can be a collective risk-diversifying rather than an incomemaximising strategy. NELM theorists analyse migration as a strategy to overcome local market and other development constraints through remitting money which can serve as investment capital (Stark 1991; Taylor 1999). In political economy a new approach designed to correct the traditional top-down macro bias is the development of microscale or 'relational' political economy research on livelihoods and commodity chains in conflict areas (Collinson 2003, 2009).

One of the most widely accepted innovations in migration theory since the 1980s has been the adoption of network theories, which focus on the collective agency of migrants and communities in organising processes of migration and incorporation (Boyd 1989; Portes and Bach 1985). ${ }^{2}$ Informal networks provide vital resources for individuals and groups. In the context of sending countries they are often analysed as transmission mechanisms for cultural capital (especially information on migration opportunities, networks and routes), while in the context of migrant incorporation into receiving societies the emphasis is more on social capital (Bourdieu and Wacquant 1992: 119)-i.e. personal relationships, family and household patterns, friendship and community ties, and mutual help in economic and social matters. A newer trend towards analysing migrant agency is to be found in transnational theory (Guarnizo et al. 2003; Portes et al. 2007; Vertovec 2004).

This brief review reflects the strength of new thinking about global connectivity in social theory, and shows how such ideas are influencing many aspects of migration research. Thus the project of elaborating a social transformation framework for the analysis of migration does not require starting from scratch. Rather the task is to bring together new approaches and insights in a detailed and systematic way so that 


\section{S. Castles}

they can serve as a coherent frame for migration theory and research methodology. This task cannot be attempted here, but one example will now be presented to show how the understanding of local experiences of migration can be enhanced through analysis of global social transformations.

\section{For Example: Migration and Labour Force Dynamics in the New Economy}

One of the most dramatic - and perhaps surprising - trends of the last 20 years has been the restructuring of labour forces in rich countries through such employment practices as subcontracting, temporary employment and casual work. Closely linked has been the expansion of informal economies and the growth of domestic-service and care-worker jobs, frequently employing women under highly exploitative conditions. Such forms of work affect natives too, but migrants are far more likely to find themselves in situations of precarious employment (Schierup et al. 2006).

Conventional analyses of labour market change often attribute the decline in working conditions and the increasing polarisation of labour markets to the ready availability of - frequently irregular - migrant workers. This allows politicians and sections of the media to advocate tighter immigration control, ostensibly to 'protect local workers'. But some social scientists argue that the causality is the other way round: economic deregulation and employer practices have created informal sector jobs, forming a pull factor for irregular migrants (Reyneri 2003). This applies most obviously in Southern Europe, but informal work is widespread throughout NorthWestern Europe, for instance in agriculture, cleaning and catering, but also (at least in Britain) for such occupations as traffic wardens and security guards-both services devolved by public authorities to subcontractors.

Analysis based on a social transformation framework would start from the position that changes in the work situation and social position of workers in advanced economies are linked to the global restructuring of investment, production and trade. The social transformation in developed countries can be seen in the closure of older industries, restructuring of labour forces, erosion of welfare states and decline of traditional working-class communities. Combined with demographic change (especially population ageing) and requirements for labour for new types of service industries, this leads to demand for migrant labour. In less-developed countries, the social transformation of modes of production and social relations already outlined above encourage emigration in search of better livelihoods and greater security. The upsurge in South-North migration can best be understood through examination of these complementary changes and their complex linkages.

Thus neoliberal restructuring has led a new global social geography. In the 1980s, Sassen (1988) showed how foreign investment and displacement of manufacturing jobs abroad had fostered new migratory streams to the USA. Linkages between global cities and distant hinterlands created situations where enormous wealth and highly remunerated professional employment coexisted with growing unskilled service industry employment and Third-World-like employment conditions in underground 
industries. The subsequent development of the new global social geography is best illustrated through local- or national-level studies.

Immanuel Ness has examined the economic transformation of New York City (Ness 2005). In the early twentieth century, immigrant labour from Southern and Eastern Europe had been crucial to the emergence of the garment, printing, meatpacking, construction and transportation industries. Industry was concentrated in 'ethnic neighbourhoods' and immigrants came to form the backbone of the city's strong labour movement. In the late twentieth century, these traditional industries were restructured, with most production jobs being moved to non-unionised 'sunbelt' states or off-shore to the Caribbean, Latin America and Asia. Many new jobs were created in retailing, personal services, and business services. The worst jobs are done by undocumented migrants from the Dominican Republic, Mexico and French West Africa, who compete for precarious and exploitative posts as supermarket workers, delivery drivers and kitchen workers (Ness 2005). As in the past, the new economy is heavily stratified on the basis of ethnicity, but this no longer provides a basis for solidarity and unionisation, because the jobs and the workers are dispersed all over the city.

The Berlin construction industry provides another example. Following German reunification in 1990 and the move of the government to Berlin, the city experienced an unprecedented building boom. Yet by 1996, 25 per cent of unemployed persons in Berlin were building workers. Some employers took on workers from Poland, who came through temporary labour schemes. Another option was to subcontract work to Portuguese firms, who could bring their own workers (at lower wages) through EU free movement provisions. In addition, many workers came as daily commuters from the former East German hinterland of Brandenburg. This competition had adverse effects on unionised building workers, many of whom were long-term foreign residents of Berlin. In the old German model of long-term employment, the firm and the trade union had been sites of inter-ethnic communication and integration. Racism against migrants had been less pronounced at work than in other social areas. The decline of this model and its replacement with contract workers thus had negative effects on social integration and inter-group relations. This was no doubt one factor behind the increase in racism and racist violence following German reunification (Hunger and Thränhardt 2001).

The garment industry provides many examples of ethnic entrepreneurship and hierarchies based on race and gender around the world (Rath 2002). In Britain, ethnic and gender-based divisions allowed the revival of clothing production after it seemed doomed to extinction through outsourcing to low-wage economies (see Phizacklea 1990). From the 1970s, the management, design and marketing of clothing became heavily concentrated in a few big and highly capitalised British retail clothing companies (Mitter 1986). Domestic clothing production declined steeply. During the 1960 s and 1970s the immigrant workforce in the garment industry had mainly been first-generation male immigrants, especially Pakistanis, Indians and Bangladeshis. Many of these workers lost their jobs, and then became contractors to the big clothing 


\section{S. Castles}

houses, setting up small formally independent sweatshops based on cheap ethnic minority or immigrant family labour. Migrant women made up the bulk of the workforce in the new sweatshops. Cost reduction was accomplished through this sector's nature as a hidden economy - which also helped the producers to evade taxation. This state of informality suited both the economic interests of the big retailers and the male ethnic middlemen contractors, who managed to keep their female workforce under control through bonds of family and ethnic community allegiance and dominance (Mitter 1986; Schierup et al. 2006: 235-7).

Each of the above cases has distinct characteristics, but also reveals recurring patterns that show the connections between specific experiences and global shifts. Taken together, these examples of labour force restructuring add up to a new process of labour market segmentation. People's chances of getting jobs depend not only on their human capital (i.e. their education and skills) but also on gender, race, ethnicity, origins and legal status. Each case reflects the complex links between labour force change and processes of social transformation in both North and South. Research strategies that concentrate on specific experiences of migrant employment and ignore such connections cannot unravel the broader dynamics of change.

\section{Conclusion}

The central aim of this paper has been to discuss some of the difficulties of theory formation in migration studies, and to suggest a possible response. The problems include surmounting disciplinary boundaries, preventing fragmentation into isolated sub-fields, fending off political or bureaucratic cooption, overcoming a bias towards receiving-country perspectives and-most important - finding appropriate theories and methodologies to reflect the complexity, diversity and contextuality of migratory processes. The solution does not lie in seeking to formulate a single (or general) theory of migration, which would almost inevitably degenerate into banality and abstraction. But nor are answers to be found by abandoning the quest for theoretical advancement on the grounds that all migratory processes are different and unique.

The suggested response is that migration researchers should seek to develop middle-range theories that can help integrate the insights of the various social sciences to understand the regularities and variations of a range of migratory processes within a given historical socio-economic constellation. Such middle-range theories can form the basis for a conceptual framework, which takes contemporary social transformation processes as a starting point, for understanding shifting patterns of human mobility. Such a conceptual framework would consist of a detailed mapping of the factors that influence migratory processes and of the connections between these factors. The examples above focused on labour-market dimensions of migration, but it is important to also include the many non-economic factors that make migration such an all-embracing human experience.

A key aspect of this conceptual framework would be that it should not restrict itself to migration, but rather seek to link analysis of migratory processes to broader social 
theory and through this to the analysis of societal change in general. The development of migration theory at this historical juncture should therefore be linked to the analysis of social transformation processes at a range of socio-spatial levels: whether a specific piece of research starts with a local phenomenon or a global one, or somewhere in-between, it needs to be based on an awareness of connectivity between localities and mediations between levels.

\section{Acknowledgements}

This is the revised version of a paper originally delivered at the conference on Theories of Migration and Social Change organised by the International Migration Institute and the Centre on Migration, Policy and Society, University of Oxford, 1-3 July 2008. I thank the participants at the conference for comments and suggestions. I also thank Hein de Haas for his detailed critique and suggestions and Han Entzinger for his helpful reviewer's comments.

\section{Notes}

[1] See http://essays.ssrc.org/developmentpapers/?page_id=3.

[2] In fact network theories were foreshadowed much earlier by theories of chain migration (Price 1963).

\section{References}

Alba, R. and Nee, V. (1997) 'Rethinking assimilation theory for a new era of immigration', International Migration Review, 31(4): 826-74.

Albrow, M. (1996) The Global Age. Cambridge: Polity.

Bakewell, O. (2007) Keeping Them in their Place: The Ambivalent Relationship between Development and Migration in Africa. Oxford: International Migration Institute, IMI Working Paper, 8.

Bauman, Z. (1998) Globalization: The Human Consequences. Cambridge: Polity.

Beck, U. (1997) Was ist Globalisierung? Frankfurt: Suhrkamp.

Beck, U. (2007) 'Beyond class and nation: reframing social inequalities in a globalizing world', British Journal of Sociology, 58(4): 679-705.

Bhagwati, J. (2003) 'Borders beyond control', Foreign Affairs, 82(1): 98-104.

Bourdieu, P. and Wacquant, L. (1992) An Invitation to Reflexive Sociology. Chicago: University of Chicago Press.

Boyd, M. (1989) 'Family and personal networks in migration', International Migration Review, 23(3): 638-70.

Brettell, C.B. and Hollifield, J.F. (eds) (2007) Migration Theory: Talking Across Disciplines. New York and London: Routledge ( $2^{\text {nd }}$ edition).

Castells, M. (1996) The Rise of the Network Society. Oxford: Blackwell.

Castells, M. (1997) The Power of Identity. Oxford: Blackwell.

Castells, M. (1998) End of Millennium. Oxford: Blackwell.

Castles, S. (2004) 'Why migration policies fail', Ethnic and Racial Studies, 27(2): 205-27.

Castles, S. (2006) 'Guestworkers in Europe: a resurrection?', International Migration Review, 40(4): 741-66.

Castles, S. (2007) 'Twenty-first century migration as a challenge to sociology', Journal of Ethnic and Migration Studies, 33(3): 351-71. 
1584 S. Castles

Castles, S. (2008) Development and Migration-Migration and Development: What Comes First? New York: Social Science Research Council, http://essays.ssrc.org/developmentpapers/wpcontent/uploads/2009/08/2Castles.pdf

Castles, S. and Delgado Wise, R. (eds) (2008) Migration and Development: Perspectives from the South. Geneva: International Organization for Migration.

Castles, S. and Miller, M.J. (2009) The Age of Migration: International Population Movements in the Modern World. Basingstoke and New York: Palgrave Macmillan and Guilford (4th edition).

CEC (2005a) Green Paper on an EU Approach to Managing Economic Migration. Brussels: Commission of the European Communities, $\operatorname{COM}(2004) 811$ final.

CEC (2005b) Communication from the Commission: Policy Plan on Legal Migration. Brussels: Commission of the European Communities, $\operatorname{COM}(2005) 669$ final.

Cohen, R. (ed.) (1995) The Cambridge Survey of World Migration. Cambridge: Cambridge University Press.

Cohen, R. and Kennedy, P. (2000) Global Sociology. Basingstoke: Palgrave.

Collinson, S. (ed.) (2003) Power, Livelihoods and Conflict: Case Studies in Political Economy Analysis for Humanitarian Action. London: Overseas Development Institute, Humanitarian Policy Group Report 13.

Collinson, S. (2009) The Political Economy of Migration Processes: An Agenda for Migration Research and Analysis. Oxford: International Migration Institute, IMI Working Paper 12, http:// www.imi.ox.ac.uk/pdfs/wp12-collinson.

Connell, R.W. (1997) 'Why is classical theory classical?', American Journal of Sociology, 102(6): 1511-57.

de Haas, H. (2006) Turning the Tide? Why 'Development Instead of Migration' Policies are Bound to Fail. Oxford: International Migration Institute, IMI Working Paper, 2.

Entzinger, H. (2003) 'The rise and fall of multiculturalism: the case of the Netherlands', in Joppke, C. and Morawska, E. (eds) Towards Assimilation and Citizenship: Immigration in Liberal Nation-States. Basingstoke: Palgrave-Macmillan, 97-118.

Faist, T. (2000) The Volume and Dynamics of International Migration and Transnational Social Spaces. Oxford: Oxford University Press.

GCIM (2005) Migration in an Interconnected World: New Directions for Action: Report of the Global Commission on International Migration. Geneva: Global Commission on International Migration, http://www.gcim.org/en/finalreport.html.

Gold, S.J. (2005) 'Migrant networks: a summary and critique of relational approaches to international migration', in Romero, M. and Magolis, E. (eds) The Blackwell Companion to Social Inequalities. Malden, MA: Blackwell, 257-85.

Guarnizo, L.E., Portes, A. and Haller, W. (2003) 'Assimilation and transnationalism: determinants of transnational political action among contemporary migrants', American Journal of Sociology, 108(6): 1211-48.

Hatton, T.J. and Williamson, J.G. (1998) The Age of Mass Migration: Causes and Economic Effects. Oxford and New York: Oxford University Press.

Hatton, T.J. and Williamson, J.G. (2005) Global Migration and the World Economy. Boston: MIT Press.

Held, D., McGrew, A., Goldblatt, D. and Perraton, J. (1999) Global Transformations: Politics, Economics and Culture. Cambridge: Polity.

Hirschman, C., Kasinitz, P. and DeWind, J. (1999) The Handbook of International Migration: The American Experience. New York: Russell Sage Foundation.

Hunger, U. and Thränhardt, D. (2001) 'Die Berliner Integrationspolitik im Vergleich der Bundesländer', in Gesemann, F. (ed.) Migration und Integration in Berlin. Opladen: Leske and Budrich, 109-25.

Joppke, C. and Morawska, E. (eds) (2003) Towards Assimilation and Citizenship: Immigration in Liberal Nation-States. Basingstoke: Palgrave Macmillan. 
King, R. (2002) 'Towards a new map of European migration', International Journal of Population Geography, 8(2): 89-106.

Kuhn, T.S. (1996) The Structure of Scientific Revolutions. Chicago and London: University of Chicago Press ( $3^{\text {rd }}$ edition).

Levitt, P. and Glick Schiller, N. (2004) 'Conceptualising simultaneity: a transnational social field perspective on society', International Migration Review, 38(3): 1002-39.

Luhmann, N. (1990) Die Wissenschaft der Gesellschaft. Frankfurt am Main: Suhrkamp.

Lussault, M. (2007) L'Homme Spatiale: La construction sociale de l'être humain. Paris: Seuil.

Manuh, T. (ed.) (2005) At Home in the World? International Migration and Development in Contemporary Ghana and West Africa. Accra: Sub-Saharan Publishers.

Massey, D.S., Arango, J., Hugo, G., Kouaouci, A., Pellegrino, A. and Taylor, J.E. (1998) Worlds in Motion, Understanding International Migration at the End of the Millenium. Oxford: Clarendon Press.

Merton, R.K. (1957) Social Theory and Social Structure. Glencoe: Free Press.

Milanovic, B. (2007) 'Globalization and inequality', in Held, D. and Kaya, A. (eds) Global Inequality: Patterns and Explanations. Cambridge and Malden, MA: Polity, 26-49.

Mitter, S. (1986) 'Industrial restructuring and manufacturing homework: immigrant women in the UK clothing industry', Capital and Class, 27: 37-80.

Ness, I. (2005) Immigrants, Unions and the New US Labor Market. Philadelphia: Temple University Press.

Parsons, T. (1951) The Social System. Glencoe: Free Press.

Penninx, R., Berger, M. and Kraal, K. (eds) (2006) The Dynamics of International Migration and Settlement in Europe. Amsterdam: Amsterdam University Press.

Petras, J. and Veltmayer, H. (2000) 'Globalisation or imperialism?', Cambridge Review of International Affairs, 14(1): 1-15.

Phizacklea, A. (1990) Unpacking the Fashion Industry: Gender, Racism and Class in Production. London: Routledge.

Polanyi, K. (2001) The Great Transformation. Boston: Beacon Press.

Portes, A. (1997) 'Immigration theory for a new century: some problems and opportunities', International Migration Review, 31(4): 799-825.

Portes, A. and Bach, R.L. (1985) Latin Journey: Cuban and Mexican Immigrants in the United States. Berkeley: University of Calfornia Press.

Portes, A. and DeWind, J. (eds) (2004a) 'Conceptual and methodological developments in the study of international migration', Special Issue, International Migration Review, 38(3).

Portes, A. and DeWind, J. (2004b) 'A cross-Atlantic dialogue: the progress of research and theory in the study of international migration', International Migration Review, 38(3): 828-51.

Portes, A., Escobar, C. and Radford, A.W. (2007) 'Immigrant transnational organizations and development: a comparative study', International Migration Review, 41(1): 242-82.

Price, C. (1963) Southern Europeans in Australia. Melbourne: Oxford University Press.

Ranis, G. (2009) Relationships between Migration and Development. New York: Social Science Research Council, http://essays.ssrc.org/developmentpapers/?page_id=3\#panel1.

Rath, J. (2002) Unravelling the Rag Trade: Immigrant Entrepreneurship in Seven World Cities. Oxford: Berg.

Reyneri, E. (2003) 'Immigration and the underground economy in new receiving South European countries: manifold negative effects, manifold deep-rooted causes', International Review of Sociology, 13(1): 117-43.

Sassen, S. (1988) The Mobility of Labour and Capital. Cambridge: Cambridge University Press.

Sassen, S. (2006) Territory, Authority, Rights: from Medieval to Global Assemblages. Princeton, NJ: Princeton University Press.

Saul, J.R. (2006) The Collapse of Globalism and the Reinvention of the World. London: Atlantic Books. 


\section{S. Castles}

Schierup, C.-U., Hansen, P. and Castles, S. (2006) Migration, Citizenship and the European Welfare State: A European Dilemma. Oxford: Oxford University Press.

Schuerkens, U. (ed.) (2004) Global Forces and Local Life-Worlds: Social Transformations. Thousand Oaks, CA: Sage.

Stark, O. (1991) The Migration of Labour. Oxford: Blackwell.

Stiglitz, J.E. (1998) Towards a New Paradigm for Development: Strategies, Policies and Processes. Geneva: World Bank, UNCTAD 1998 Prebisch Lecture.

Stiglitz, J.E. (2002) Globalization and its Discontents. London: Penguin.

Taylor, J.E. (1999) 'The new economics of labour migration and the role of remittances in the migration process', International Migration, 37(1): 63-88.

UNDESA (2005) Trends in Total Migrant Stock: The 2005 Revision. New York: United Nations Department of Economic and Social Affairs.

UNDP (2009) Human Development Report 2009: Overcoming Barriers: Human Mobility and Development. New York: United Nations Development Programme, http://hdr.undp.org/en/ reports/global/hdr2009/.

Urry, J. (2007) Mobilities. Cambridge: Polity.

Vasta, E. (2007) 'From ethnic minorities to ethnic majority policy: multiculturalism and the shift to assimilationism in the Netherlands', Ethnic and Racial Studies, 30(5): 713-40.

Vasta, E. and Vuddamalay, V. (eds) (2006) International Migration and the Social Sciences: Confronting National Experiences in Australia, France and Germany. Basingstoke: Palgrave Macmillan.

Vertovec, S. (2004) 'Migrant transnationalism and modes of transformation', International Migration Review, 38(3): 970-1001.

Weiss, L. (1998) The Myth of the Powerless State: Governing the Economy in a Global Era. Cambridge: Polity Press.

Wimmer, A. and Glick Schiller, N. (2003) 'Methodological nationalism, the social sciences and the study of migration', International Migration Review, 37(3): 576-610. 